Marquette University

e-Publications@Marquette

College of Professional Studies Faculty Research

and Publications

Professional Studies, College of

$2-1-2010$

The Relationship between Nurses' Religiosity and Willingness to Let Patients Control the Conversation about End-of-Life Care

Christopher Stephanie

Marquette University

Post-print. Patient Education and Counseling, Volume 78, No. 1 (2010), DOI: 10.1016/

j.pec.2009.05.018. Used with permission. 


\title{
The Relationship between Nurses' Religiosity and Willingness to Let Patients Control the Conversation about End-of-Life Care
}

\author{
Stephanie A. Christopher \\ College of Professional Studies, Marquette University \\ Milwaukee, WI
}

Objective: The study attempts to examine the relationship between nurses' religious beliefs and how nurses communicate with patients.

Method: An online census survey was administered to graduate students in the School of Nursing at a Midwestern university. The survey was designed to measure: relational control, as measured by the subscales of dominance and task orientation in Burgoon and Hale's scale of relational communication; clinician empathy, as measured by the Jefferson scale of clinician empathy; and intrinsic and extrinsic religiosity, whether religious views are held for deep personal reasons or social reasons, as measured by the Maltby and Lewis scale. Data were analyzed using multiple regressions and one-way ANOVAs.

Results: Intrinsic religiosity and empathy were both associated with the willingness to relinquish relational control in certain, specific contexts, such as end-of-life care.

Conclusion: Nurses who scored higher on a scale of intrinsic religious beliefs were more willing to let patients take control of conversations about end-oflife care.

Practice implications: A nurse's religious beliefs can enhance the clinical experience without the nurse trying to impose his or her beliefs on the patient, as the nurse works to make sure the patient's religious beliefs are upheld. 
NOT THE PUBLISHED VERSION; this is the author's final, peer-reviewed manuscript. The published version may be accessed by following the link in the citation at the bottom of the page.

\section{Introduction}

Nurses are taught to approach communication in the clinical setting in a purposeful and direct manner, but discussions about certain topics, such as end-of-life care, may raise ambiguities as the topic evokes personal religious values, both for the nurse and for the patient. Patients have better experiences and clinical outcomes when they are allowed to be active in conversations about their own health care [1], but although nurses are encouraged to empower patients to play an active role in their health care, nurses may not always be willing to give patients control of the clinical conversation $[2,3]$. The purpose of this study is to examine the relationship of the religiosity of a nurse and the nurse's willingness to give the patient relational control of conversations about end-of-life care.

\subsection{Relational Control Theory}

Relational control, or relational communication, focuses on the ebb and flow of conversations. The person in the conversation who adjusts the most to the behavior of the other is exhibiting lower levels of relational control [4]. Relational control assumes that all messages contain both a relational and a content element. Messages communicate a piece of information and something about the nature of the relationship between the two conversation partners [5].

Millar and Rogers offer three dimensions of interpersonal relations: control, trust, and intimacy [5]. Control is particularly relevant to patient-clinician relationships. The dimension of control is defined by Millar and Rogers as "establishing the right to define, direct and, delimit the actions of the dyad at the current moment" [5] (p. 120). In a temporal sense, control is both static and dynamic, since it must be continually negotiated in changing conditions.

Several studies have measured relational control in physicianpatient interactions. Patients attempted to assert control almost as often as physicians (126 times vs. 243 times), but physicians were more likely to assume control of the conversation when such control was offered (618 vs. 100) [6]. Another study found patients attempted control almost as often as physicians, but patients yielded control

Patient Education and Counseling, Vol. 78 (February 2010): pg. 250-255. DOI. This article is (c) Elsevier and permission has been granted for this version to appear in e-Publications@Marquette. Elsevier does not grant permission for this article to be further copied/distributed or hosted elsewhere without the express permission from Elsevier. 
twice as often as physicians [7]. In institutional and home hospice care, physicians attempted control almost twice as often as patients $[8]$.

Contemporary nurses are encouraged to empower their patients by giving them information and sharing in decision-making, but in practice this does not always happen [2]. Nurses often have a goal of gaining the patient's compliance with a specific treatment plan, and while they do not set aside specific time to try to control the conversation, they may integrate control and compliance-gaining strategies throughout the interactions[3]. When nurses are unwilling to share power, a barrier to communication is created that prevents nurses from letting patients play an active role in their care. Many interactions between nurses and patients are limited to routine interactions and questions that do not allow for the personalization of communication needed for patients to play an active role in their health care [9]. One study found that diabetes patients who had nurses that exhibited controlling behaviors, rather than patientcentered behaviors, had poor control of their diabetes, though it is not clear if the controlling behavior of the nurses was a cause or a response to patient behavior[10]. Nurse communication with elderly patients is especially recognized as a potential paradox, since controlling language can persuade patients to take measures that will aid in their recovery and independence; however, such language also contributes to the patient's feeling of helpless dependence [11]. Sharing information is another method of relinquishing control to patients. But nurses do not always see information sharing as important, especially if they believe it may cause harm [12].

Communication of control when discussing issues, such as endof-life care, is not always direct. Nurses, patients and patient family members often engage in surreptitious and ambiguous dialogue about end-of-life care decision-making, especially when the discussion concerns actions that would hasten death [13]. The nurse may try to take control of these conversations, especially if the conversation is taking a direction seen as conflicting with the nurse's personal or religious beliefs [13].

Patient Education and Counseling, Vol. 78 (February 2010): pg. 250-255. DOI. This article is @ Elsevier and permission has been granted for this version to appear in e-Publications@Marquette. Elsevier does not grant permission for this article to be further copied/distributed or hosted elsewhere without the express permission from Elsevier. 
NOT THE PUBLISHED VERSION; this is the author's final, peer-reviewed manuscript. The published version may be accessed by following the link in the citation at the bottom of the page.

\subsection{Religiosity of Nurses}

Religiosity refers to behaviors and attitudes a person has with regards to a particular religion [14]. Religiosity examines how individuals' religious attitudes affect how they live and interact with others. Religiosity is measured by assessing whether the beliefs are intrinsic or extrinsic. Intrinsic-oriented religious believers seek to live their religion in all they do. They embrace and internalize their adopted creed [15]. Intrinsic believers are found to be less prejudiced toward others unlike them, or who believe other creeds [15]. Extrinsic believers seek to use their religion to serve other ends, such as safety, security, and social status. These believers tend to hold lightly or selectively the beliefs of their creed [15]. Generally, older people and women tend to be higher in intrinsic religiosity $[16,17]$.

There are a limited number of studies examining religiosity and religious attitudes in nurses. A study of Israeli oncology nurses examined the interaction between religiosity, spiritual well-being, and attitudes toward spiritual care $[18,19]$. Spiritual well-being, extrinsic religiosity, and education had direct, significant, positive relationships to attitudes about spiritual care. The mediating variables of spiritual well-being, intrinsic religiosity and extrinsic religiosity accounted for the greatest contribution to the indirect effects on attitudes toward spiritual care [19]. A study of nurse practitioners found that those who scored higher on scales of personal spirituality rated spiritual care of patients as more important than nurses who did not score highly on personal spirituality [20].

\subsection{Empathy}

Empathy is defined as the mental capacity to appreciate another person's feelings without joining them. In the medical context, empathy is an uncritical view of a patient's inner feelings and experiences. Health care provider empathy encompasses understanding patients' experiences, examining emotions in health care, and thinking like the patient [21]. The empathetic physician accepts the patient's feelings and actively uses his or her own expertise to read the emotional state of the patient [22]. Special

Patient Education and Counseling, Vol. 78 (February 2010): pg. 250-255. DOI. This article is @ Elsevier and permission has been granted for this version to appear in e-Publications@Marquette. Elsevier does not grant permission for this article to be further copied/distributed or hosted elsewhere without the express permission from Elsevier. 
NOT THE PUBLISHED VERSION; this is the author's final, peer-reviewed manuscript. The published version may be accessed by following the link in the citation at the bottom of the page.

emphasis is placed on listening and empathy skills in the training of nurses [23].

\subsection{Hypotheses Drawn from the Literature Review}

It is important for patients to have some control of their health care, but nurses do not always let patients have that control $[1,9]$. From the literature review, we hypothesized that religiosity will potentially influence relational control. Since intrinsically religious people also tend to be more empathetic to people with differing religious beliefs [15], we hypothesize that empathy may also influence relational control. Therefore, in formulating the research plan, we have decided to examine religiosity and empathy and their results on relational control separately, and then examine if empathy acted as an intervening variable in the relationship between religiosity and relational control. The first version of our hypothesized model is seen in Fig. 1.

The literature review also led us to include certain demographic characteristics in the proposed model. Gender and age were included in the hypothesized model because gender has been shown to impact empathy, and gender and age impact religiosity $[16,17,24]$. Socioeconomic status in childhood was included because Roter and Hall [24] found that physicians who had risen in socioeconomic status from childhood were more likely to give control to patients who sought it.

Four hypotheses were proposed to guide the examination of the research question (also illustrated in Fig. 2):

RQ1. Does the nurse's religiosity impact his or her willingness to relinquish relational control in conversations with patients about endof-life care?

H1. Those who are high in intrinsic religiosity will display more empathy toward patients.

H2. Those who are high in empathy will be more willing to relinquish relational control in conversations with patients about end-of-life care.

Patient Education and Counseling, Vol. 78 (February 2010): pg. 250-255. DOI. This article is @ Elsevier and permission has been granted for this version to appear in e-Publications@Marquette. Elsevier does not grant permission for this article to be further copied/distributed or hosted elsewhere without the express permission from Elsevier. 
H3. Those who are high in intrinsic religiosity will exhibit more willingness to relinquish relational control in conversations with patients about end-of-life care.

H4. When empathy is introduced as an intervening variable, the relationship between intrinsic religiosity and willingness to relinquish relational control will be decreased.

\section{Method}

\subsection{Description of Sample}

The sample included graduate students in the College of Nursing at a religiously affiliated Midwestern university. Although religiously affiliated, religious adherence is not a requirement for admission into the program. Graduate students had at least 1 year of nursing experience prior to entering the program, and many students were full-time nurses attending graduate school part-time.

A total of 231 students were asked to participate and sent a link to the web survey. The introductory letters, e-mails, and the survey were approved by the university's Institutional Review Board prior to the start of the study. The original email and survey link were sent successfully to 225 students on 1 February 2006. Reminder e-mails were sent to non-respondents on the 5th and 7th days after the initial release of the survey. The online survey program enabled the researcher to send the reminder e-mails without knowing the identity of the non-respondents. A total of 115 completed surveys were collected, a $51.1 \%$ return rate.

Those who responded were primarily female, Catholic, more than 30 years of age and had more than 10 years' experience in nursing. The demographic characteristics of the respondents can be seen in Table 1.

\subsection{Study Design}

An online census survey of nursing graduate students was conducted to examine the interaction between relational control and religiosity in the context of discussions about end-of-life care. The

Patient Education and Counseling, Vol. 78 (February 2010): pg. 250-255. DOI. This article is @ Elsevier and permission has been granted for this version to appear in e-Publications@Marquette. Elsevier does not grant permission for this article to be further copied/distributed or hosted elsewhere without the express permission from Elsevier. 
survey was designed to assess intrinsic and extrinsic religious orientation, empathy, relational control in three clinical contexts, religious affiliation, and relevant demographic information.

\subsection{Measurement}

Relational control is the dependent variable. The dimension of control is defined by Millar and Rogers as "establishing the right to define, direct and, delimit the actions of the dyad at the current moment" and can be measured by redundancy, dominance, and power [5]. The relational control questions in the survey are based on Burgoon and Hale's [25] scale of relational communication. In developing the instrument, Burgoon and Hale [25] found 8 factors that emerged with eigenvalues greater than one. The questions used in the present study were from the subscales of dominance and taskorientation which emerged as relatively independent from the other factors [25]. The questions used a 7-point Likert scale that ran from 1 - strongly disagree to 7 - strongly agree.

Based on Burgoon and Hale's scale, the present study used a set of 10 statements to examine relational control in three different patient settings. The respondents were asked to consider the variables in three clinical contexts: how the nurses normally interact with patients; their interactions with a patient who has influenza; and their discussion with a patient about end-of-life care.

The relational control variables are seen in Table 2.

Since not all of Burgoon and Hale's variables were used, a factor analysis was run on the 10 variables used in the present study. Two of the variables were removed from the analysis: "I try to win the patient's favor" and "I am more interested in social conversation than the task at hand." The two variables did not factor highly in the analysis. Cronbach's alpha for the 8 variables was .605. Three factors emerged from the remaining 8 variables, with initial eigenvalues of $2.340,1.628$ and 1.077 . The factors account for $29.25 \%, 20.35 \%$ and $13.47 \%$ of the variance respectively. The factors can be classified as: retaining control; staying on task but not trying to influence; and work-oriented but having patient approval.

Patient Education and Counseling, Vol. 78 (February 2010): pg. 250-255. DOI. This article is (C Elsevier and permission has been granted for this version to appear in e-Publications@Marquette. Elsevier does not grant permission for this article to be further copied/distributed or hosted elsewhere without the express permission from Elsevier. 
In addition to the Burgoon and Hale relational control scale questions, the author wrote two additional questions intended to reflect practical clinical circumstances when a nurse may give a patient relational control of a situation or conversation. These were not intended to be a part of the Burgoon and Hale scale, but were intended to examine relational control in another way. The variables were based on previous literature regarding how control can be relinquished and claimed in a conversation. Those variables were: "I would want a patient to interrupt if I suggested a treatment contrary to his or her religious beliefs" and "I would not feel comfortable discussing religious topics unless the patient brought it up first." These two variables were analyzed separately from the relational control factors derived from the Burgoon and Hale scale.

Intrinsic religiosity was measured by a modified scale created by Maltby and Lewis [26] that had good response rates for religious and non-religious groups. Maltby and Lewis modified an existing intrinsicextrinsic scale to be relevant to non-religious participants. When they used a three-point yes-no-uncertain scale, more non-religious participants completed the survey than with a yes-no scale [26]. For the current study, all 19 Maltby and Lewis questions were asked using a seven-point strongly agree-strongly disagree scale, including a neutral point in the middle "neither agree nor disagree." This neutral point allows for the participation of non-religious samples, without sacrificing a rich range of data. Seven of the religiosity variables were used to create the intrinsic religiosity index and the other 12 variables were used to create the extrinsic religiosity index [26]. Cronbach's alpha was run for the variables collected in the present study, using the seven-point instead of the three-point scale. Cronbach's alpha for the intrinsic scale was .820; Cronbach's alpha for extrinsic scale was .555. Intrinsic religiosity variables included statements, such as: "It is important for me to spend time in private thought and prayer." Variables that measured extrinsic religious belief included: "I go to church because it helps me make friends."

Empathy was measured using the Jefferson empathy scale, which was designed to measure empathy in medical contexts [21]. The empathy scale consisted of 19 variables including: "A nurse's

Patient Education and Counseling, Vol. 78 (February 2010): pg. 250-255. DOI. This article is @ Elsevier and permission has been granted for this version to appear in e-Publications@Marquette. Elsevier does not grant permission for this article to be further copied/distributed or hosted elsewhere without the express permission from Elsevier. 
understanding of their patients' feelings and the feelings of the patients' families is a positive treatment factor" and "Patients feel better when their feelings are understood by their providers." To investigate the underlying structure of the scale when the scale was originally developed by Hojat et al., the data were subjected to factor analysis using principal component factoring with orthogonal varimax factor rotation. Four factors emerged with an eigenvalue greater than 1 , accounting for $56 \%$ of the total variance. Those four factors were: the physician's view of the world from the patient's perspective; understanding the patient's experience, feelings, and clues; ignoring emotions in patient care; and thinking like the patient [21].

\subsection{Statistics}

The data were analyzed using Statistical Package for the Social Science (SPSS) using hierarchical multiple regressions. The research question being asked is: Does the medical provider's religiosity impact his or her willingness to relinquish relational control in conversation with patients about end-of-life care?

Descriptive statistics were run to find the mean, median, distribution, and standard deviation of the variables so that they could be standardized in preparation for statistical analysis. Variables were standardized so the Z-scores could be used in analysis. Data from the nurse communication survey was analyzed with a series of hierarchical multiple regressions for each of the above hypotheses, which were used as correlation analyses for the proposed hypotheses.

For hypothesis one, a hierarchical multiple regression was used to test the relationship between intrinsic religiosity and empathy. For this hypothesis, empathy is the dependent variable. There are four different factors in the empathy variable: view of world from patient's perspective; understanding patient experience; ignoring emotions; and thinking like the patient. The variables were entered in successive blocks: (1) demographics: age, gender, and years of nursing experience and (2) religiosity: intrinsic and extrinsic factors.

For $\mathrm{H} 2$, the variables were entered in successive blocks: (1) demographics: age, gender, and years of nursing experience, and (2)

Patient Education and Counseling, Vol. 78 (February 2010): pg. 250-255. DOI. This article is @ Elsevier and permission has been granted for this version to appear in e-Publications@Marquette. Elsevier does not grant permission for this article to be further copied/distributed or hosted elsewhere without the express permission from Elsevier. 
four empathy factors. Regressions were calculated for the three relational control factors (retaining control; staying on task but not trying to influence; and work-oriented but having patient approval) in three conditions: a normal interaction with a patient, an interaction in which a patient has influenza, and an interaction in which end-of-life care planning is being discussed with the patient.

For H3, the variables were entered in successive blocks: (1) demographics: age, gender, and years of nursing experience and (2) two religiosity factors: intrinsic and extrinsic. Regressions were calculated for the three relational control factors in the three conditions.

$\mathrm{H} 4$ predicts that when empathy is introduced as an intervening variable, the relationship between intrinsic religiosity and willingness to relinquish relational control will be decreased. For this hypothesis, the variables were entered in successive blocks: (1) demographics: age, gender, and years of nursing experience, (2) four empathy factors, and (3) two religiosity factors: intrinsic and extrinsic.

Regressions were calculated for the three relational control factors in the three conditions. The regressions for $\mathrm{H} 2-\mathrm{H} 4$ were also run with individual variables, seen in Table 2, that measured practical manifestations of relational control, but were not part of the Burgoon and Hale relational control scale.

\section{Results}

Hypothesis one was not upheld. All of the nurses were high in empathy, such that there was no statistically significant variance based on intrinsic religiosity (see Table 1 in Appendix). The empathy variables were all on a Likert-type 1-7 scale, and the means for the all empathy variables averaged 5 or higher, showing a high level of empathy among all the nurse respondents.

$\mathrm{H} 2$ was upheld in part. None of the regressions with the factors based on the Burgoon and Hale relational control scale produced statistically significant results (see Table 2 in Appendix). The two variables asking about practical manifestations of relational control did

Patient Education and Counseling, Vol. 78 (February 2010): pg. 250-255. DOI. This article is @ Elsevier and permission has been granted for this version to appear in e-Publications@Marquette. Elsevier does not grant permission for this article to be further copied/distributed or hosted elsewhere without the express permission from Elsevier. 
produce significant results in the direction hypothesized (see Table 3). The results show a relationship between higher levels of empathy and willingness of the nurse to give the patient control in those specific circumstances. The results do not necessarily indicate causality, but do indicate a possible relationship between empathy and the willingness to give the patient relational control in those specific contexts.

H3 was upheld in part. None of the regressions with the factors based on the Burgoon and Hale scale produced statistically significant results (see Table 4 in Appendix). But the two variables asking about practical manifestations of relational control did produce significant results, though not in the direction hypothesized. Empathy did not appear to be an intervening variable, but possibly enhances the effect of religiosity on relational control, as seen in Table 5 . The results indicate the possibility of a relationship in which both empathy and religiosity contribute to a nurse's willingness to let a patient have control in certain, specific contexts.

\section{Discussion and Conclusions}

\subsection{Discussion}

Relational control is important because it has tangible patient outcomes. Cecil [1] found less assertive physicians, who made controlling comments but did not dominate the entire conversation, had better rates of patient compliance and satisfaction than physicians who dominated the entire conversation. But clinicians are not always willing to give this control nor are patients always willing to take it when offered. Contemporary nurses are encouraged to empower patients by giving them the information they need to make health decisions, but this does not always happen [2]. Nurses may not be willing to share power or to engage in direct conversation about topics that may come into conflict with religious values $[2,9,13]$.

The study had limited success in examining the relationship between empathy, intrinsic religiosity, and willingness to let the patient take active control of the conversation. The empathy finding is relevant in justifying and improving empathy training among all medical providers. The religiosity finding shows that religiosity may

Patient Education and Counseling, Vol. 78 (February 2010): pg. 250-255. DOI. This article is @ Elsevier and permission has been granted for this version to appear in e-Publications@Marquette. Elsevier does not grant permission for this article to be further copied/distributed or hosted elsewhere without the express permission from Elsevier. 
make a clinician even more willing to give the patient control so the patient can follow his or her own beliefs. The finding coincides with other research in which nurses who scored higher on other scales of religiosity, such as scales of personal spirituality, rated the importance of patient spiritual care as more important than those who did not score as highly on personal spirituality $[19,20]$. Both findings shed light on clinician traits that may be associated with helping patients have an active voice in their own care and a willingness to engage in direct conversations about topics that may be influenced by religious values, rather than the ambiguous tone found in previous studies of end-of-life care conversations [13].

The results lead to a new possible model of the interaction between religiosity, empathy, and relational control, seen in Fig. 3. The model shows that both empathy and intrinsic religiosity have a positive relationship with the willingness of the nurse to give up relational control to the patient in particular contexts.

This study only begins to examine the relationship of nurses' religiosity, empathy, and communication behaviors. There are several limitations to consider. The relational control scales drawn from the scale by Burgoon and Hale did not yield significant results, which may have been due to the difficulty of applying these questions to a nursing care situation. The scales were created for respondents to think back to a conversation they had with a specific person and rate their behavior. It is much easier to have a respondent think back to the last conversation with their spouse than to ask a nurse to think back to a conversation they have had with a patient, when they have had so many patients over the years. The greatest success in the present study was with questions that asked how a nurse would behave in certain scenarios. Respondents seem better equipped to answer these scenario questions, which still draw upon their nursing experience but do not ask them to remember one conversation out of many. The psychometric properties of the two relational control questions that yielded significant results should be further tested in future studies, and additional post hoc testing with a larger sample should be performed to further test the properties of these questions. Though the population of graduate nursing students had a rich range and depth of nursing experience, future studies should seek a wider range

Patient Education and Counseling, Vol. 78 (February 2010): pg. 250-255. DOI. This article is @ Elsevier and permission has been granted for this version to appear in e-Publications@Marquette. Elsevier does not grant permission for this article to be further copied/distributed or hosted elsewhere without the express permission from Elsevier. 
of nurses, including those who have completed their nursing education and those without advanced nursing degrees.

\subsection{Conclusion}

Measuring and studying willingness to give up relational control in medical contexts is not as simple as "How can we get nurses to give up control more often?" It is a difficult balance to strike. Nurses have an obligation to act in the best interest of the patient. It may become necessary to be assertive with a patient when discussing necessary treatments. It may not always be in the best interest of the patient to let them make decisions in the course of health care $[10,11]$. But patients have better health outcomes when they have some control over their health care and can raise questions with their nurse. It is not a matter of simply measuring the nurse's relational control, but examining their willingness to relinquish relational control in appropriate contexts, while still remaining true to their obligations to provide the best care for the patient.

\subsection{Practice Implications}

The potential relationship between intrinsic religiosity and willingness to relinquish relational control does not mean that health care organizations should encourage their employees to be religious. The decision to adhere to any religion is a highly personal one. This study demonstrates that religiosity does not mean a nurse is going to necessarily advocate a treatment that is in line with the nurse's religious beliefs. Rather, the nurse's religiosity may make them more willing to advocate that the patient receives treatment that is in line with the patient's religious beliefs, whatever those beliefs may be.

\section{Acknowledgements}

The research was conducted when the author was a Master of Arts student in the J. William and Mary Diederich College of Communication at Marquette University. The author would like to acknowledge her Master's thesis committee: Dr. Robert Griffin and Dr. William Thorn of the J. William and Mary Diederich College of

Patient Education and Counseling, Vol. 78 (February 2010): pg. 250-255. DOI. This article is @ Elsevier and permission has been granted for this version to appear in e-Publications@Marquette. Elsevier does not grant permission for this article to be further copied/distributed or hosted elsewhere without the express permission from Elsevier. 
NOT THE PUBLISHED VERSION; this is the author's final, peer-reviewed manuscript. The published version may be accessed by following the link in the citation at the bottom of the page.

Communication at Marquette University and Dr. Kerry KosmoskiGoepfert of the College of Nursing at Marquette University.

\section{Appendix A. Supplementary Data}

Supplementary data associated with this article can be found, in the online version, at doi:10.1016/j.pec.2009.05.018.

\section{References}

[1] Cecil DW. Relational control patterns in physician-patient clinical encounters: continuing the conversation. Health Commun $1998 ; 10: 125$.

[2] Henderson S. Power imbalance between nurses and patients: a potential inhibitor of partnership in care. J Clin Nurs 2003;12:501-8.

[3] Vivian BG, Wilcox JR. Compliance communication in home health care: a mutually reciprocal process. Qual Health Res 2000;10:103-16.

[4] Millar FE, Rogers LE. A relational approach to interpersonal communication. In: Miller GR, editor. Explorations in interpersonal communication. Beverly Hills, CA: Sage; 1976.

[5] Millar FE, Rogers LE. Relational dimensions of interpersonal dynamics. In: Roloff MR, Miller GR, editors. Interpersonal process: new directions in communication research. Newbury Park, CA: Sage; 1987.

[6] von Friederichs-Fitzwater MM, Gilgun J. Relational control in physicianpatient encounters. Health Commun 2001;13:75-87.

[7] O'Hair D. Dimensions of relational communication and control during physician-patient interactions. Health Commun 1989;1:97-115.

[8] Von Friederichs-Fitzwater MM, Callahan EJ, Flynn N, Williams J. Relational control in physician-patient encounters. Health Commun 1991;3:1736.

[9] Hewinson A. Nurses' power in interactions with patients. J Adv Nurs $1995 ; 21: 75-82$.

[10] Street Jr RL, Piziak VK, Carpentier WS, Herzog J, Hejl J, Skinner G, McLellan L. Provider-patient communication and metabolic control. Diabetes Care 1993;16:714-21.

[11] Lancely $A$. Use of controlling language in the rehabilitation of the elderly. J Adv Nurs 1985;10:125-35.

[12] Tuckett AG. The care encounter: pondering caring, honest communication and control. Int J Nurs Pract 2005;11:77-84.

[13] Lowe Volker D. Oncology nurses' experiences with requests for assisted dying from terminally ill patients with cancer. Oncol Nurs Forum Online 2001;28:39-49.

[14] Sulmasy DP. Addressing the religious and spiritual needs of dying patients. Western J Med 2001;175:251-4.

Patient Education and Counseling, Vol. 78 (February 2010): pg. 250-255. DOI. This article is (c) Elsevier and permission has been granted for this version to appear in e-Publications@Marquette. Elsevier does not grant permission for this article to be further copied/distributed or hosted elsewhere without the express permission from Elsevier. 
NOT THE PUBLISHED VERSION; this is the author's final, peer-reviewed manuscript. The published version may be accessed by following the link in the citation at the bottom of the page.

[15] Allport GW, Ross JM. Personal religious orientation and prejudice. J Personal Soc Psychol 1967;5:432-43.

[16] Watson PJ, Howard R, Hood Jr RW, Morris RJ. Age and religious orientation. Rev Religious Res 1988;29:271.

[17] Stark R. Physiology and faith: addressing the "Universal" gender difference in religious commitment. J Sci Study Religion 2002;41:495507.

[18] Musgrave CF, McFarlane EA. Intrinsic and extrinsic religiosity, spiritual wellbeing, and attitudes toward spiritual care: a comparison of Israeli Jewish oncology nurses' scores. Oncol Nurs Forum Online 2004;31:1179-83.

[19] Musgrave CF, McFarlane EA. Israeli oncology nurses' religiosity, spiritual wellbeing, and attitudes toward spiritual care: a path analysis. Oncol Nurs Forum Online 2004;31:321-7.

[20] Stranahan S. Spiritual perception, attitudes about spiritual care, and spiritual care practices among nurse practitioners. Western J Nurs Res 2001;23:90-104.

[21] Hojat M, Mangione S, Nasca TJ, Cohen MJM, Gonnella JS, Erdmann JB, Veloski J, Magee M. The Jefferson scale of physician empathy: development and preliminary psychometric data. Educ Psychol Measur 2001;61:349-65.

[22] Friedrichsen MJ, Strang PM, Carlsson ME. Breaking bad news in the transition from curative to palliative cancer care-patient's view of the doctor giving the information [see comment]. Supp Care Cancer 2000;8:472-8.

[23] Sieh A, Brentin LK. The nurse communicates, vol. xiv. Philadelphia: W.B. Saunders Co.; 1997, 310 p..

[24] Roter D, Hall JA. Doctors talking with patients/patients talking with doctors: improving communication in medical visits, vol. xvi, 1st ed., Westport, CT: Praeger; 1992, 238 p..

[25] Burgoon JK, Hale JL. Validation and measurement of the fundamental themes of relational communication. Commun Monogr 1987;54:19.

[26] Maltby J, Lewis CA. Measuring intrinsic and extrinsic orientation toward religion: amendments for its use among religious and non-religious samples. Person Individual Differ 1996;21:937-46.

Patient Education and Counseling, Vol. 78 (February 2010): pg. 250-255. DOI. This article is @ Elsevier and permission has been granted for this version to appear in e-Publications@Marquette. Elsevier does not grant permission for this article to be further copied/distributed or hosted elsewhere without the express permission from Elsevier. 
NOT THE PUBLISHED VERSION; this is the author's final, peer-reviewed manuscript. The published version may be accessed by following the link in the citation at the bottom of the page.

\section{Appendix}

Fig. 1: Hypothesized Interaction between Religiosity, Empathy, and Relational Control

\begin{tabular}{|l|l|l|l|}
\hline $\begin{array}{l}\text { Provider } \\
\text { Intrinsic } \\
\text { Religiosity }\end{array}$ & $\longrightarrow \begin{array}{l}\text { Empathy for } \\
\text { patient } \\
\text { (Internening nariable) }\end{array}$
\end{tabular}

Fig. 2: Hypothesized Interaction between Religiosity, Empathy, and Relational Control, with Covariates

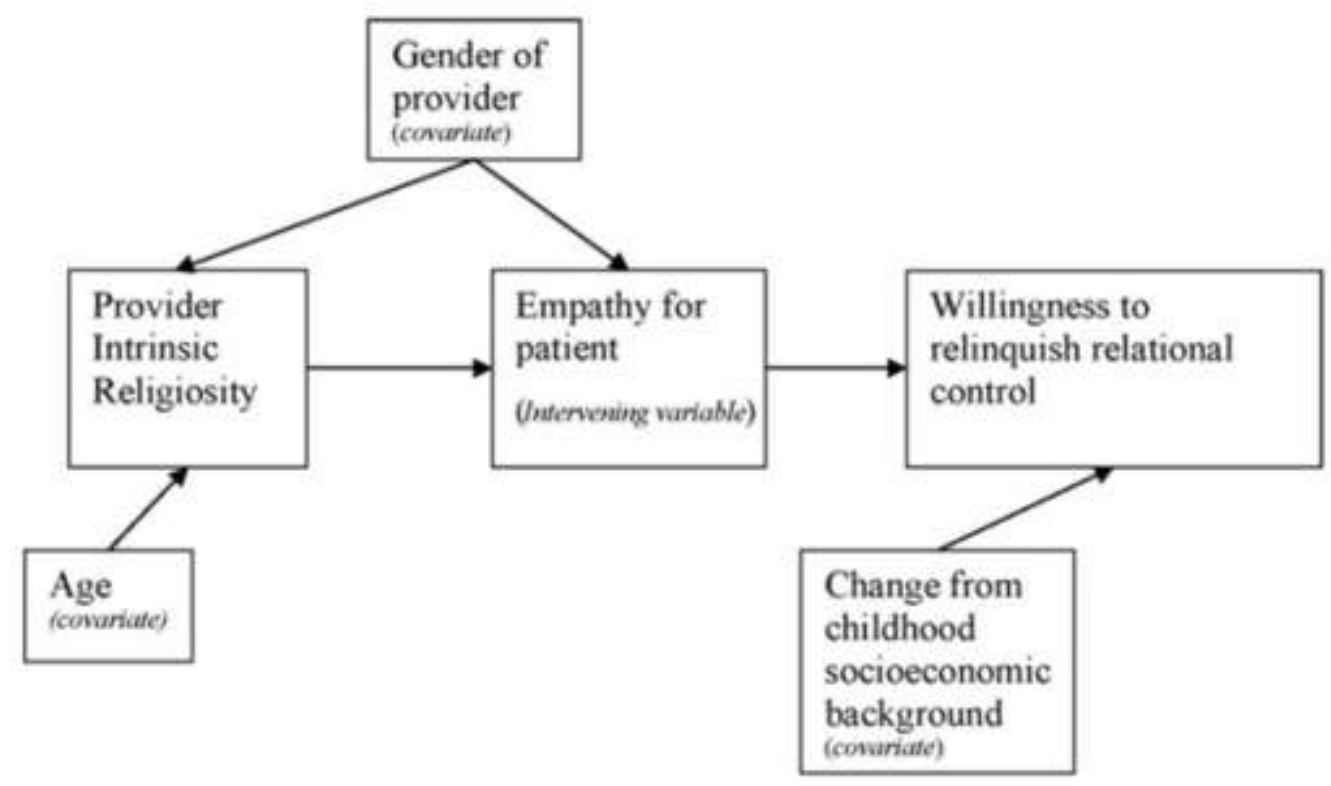

Patient Education and Counseling, Vol. 78 (February 2010): pg. 250-255. DOI. This article is (C) Elsevier and permission has been granted for this version to appear in e-Publications@Marquette. Elsevier does not grant permission for this article to be further copied/distributed or hosted elsewhere without the express permission from Elsevier. 
NOT THE PUBLISHED VERSION; this is the author's final, peer-reviewed manuscript. The published version may be accessed by following the link in the citation at the bottom of the page.

Fig. 3: Revised Model of the Interaction between Religiosity, Empathy, and Relational Control

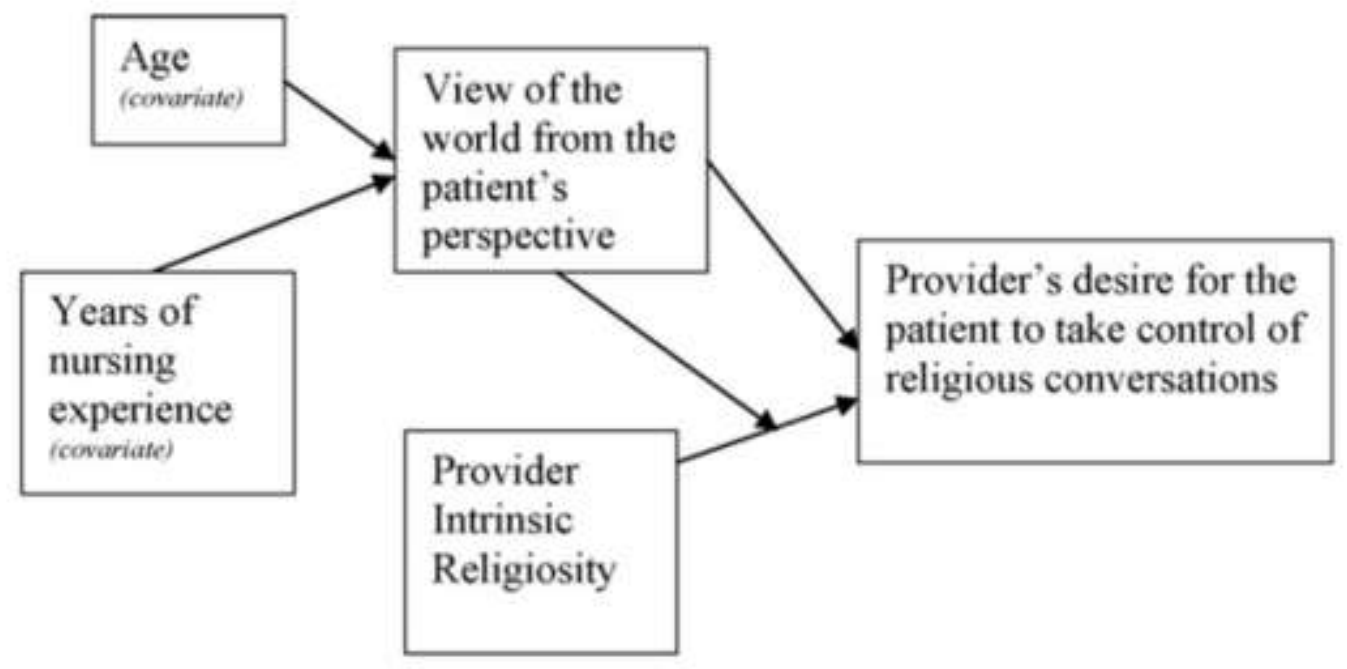

Patient Education and Counseling, Vol. 78 (February 2010): pg. 250-255. DOI. This article is @ Elsevier and permission has been granted for this version to appear in e-Publications@Marquette. Elsevier does not grant permission for this article to be further copied/distributed or hosted elsewhere without the express permission from Elsevier. 
NOT THE PUBLISHED VERSION; this is the author's final, peer-reviewed manuscript. The published version may be accessed by following the link in the citation at the bottom of the page.

\section{Table 1: Respondent Demographics}

\begin{tabular}{lrr}
\hline & No. of responding & $(\%)$ \\
\hline Gender & & \\
Male & 6 & 5.2 \\
Female & 98 & 85.2 \\
No response & 11 & 9.6 \\
Age & & \\
$23-29$ & 35 & 30.4 \\
$30-39$ & 30 & 26.1 \\
$40-49$ & 23 & 20.0 \\
$50-59$ & 16 & 13.9 \\
No response & 11 & 9.6 \\
Reported religious affiliation & & \\
Catholic & 53 & 46.1 \\
Protestant & 14 & 12.2 \\
Christian-other & 27 & 23.5 \\
Buddhist & 1 & .8 \\
Latter-Day Saints & 1 & .8 \\
Agnostic & 2 & 1.7 \\
Reported "None" & 6 & 5.2 \\
No response & 11 & 9.6 \\
Years of nursing experience & & \\
More than 10 years & 38 & 33.0 \\
7-10 years & 14 & 12.2 \\
4-6 years & 7 & 6.1 \\
1-3 years & 21 & 18.3 \\
Less than 1 year & 24 & 7.8 \\
No response & 9 & \\
\hline
\end{tabular}

Patient Education and Counseling, Vol. 78 (February 2010): pg. 250-255. DOI. This article is @ Elsevier and permission has been granted for this version to appear in e-Publications@Marquette. Elsevier does not grant permission for this article to be further copied/distributed or hosted elsewhere without the express permission from Elsevier. 
NOT THE PUBLISHED VERSION; this is the author's final, peer-reviewed manuscript. The published version may be accessed by following the link in the citation at the bottom of the page.

\section{Table 2: Relational Control Variables}

Relational control variables (from Burgoon and Hale)

-I attempt to persuade the patient

-I do not attempt to influence the patient

-1 try to control the interaction

-I do not try to win the patient's favor

-I have the upper hand in the conversation

-I want to stick to the main purpose of the interaction

- I am very work-oriented

-I am more interested in working on the task at hand than having a social conversation

Additional relational control variables (by author)

-I would want a patient to interrupt if I suggested a treatment contrary to his or her religious beliefs

-I would not feel comfortable discussing religious topics unless the patient brought it up first 
NOT THE PUBLISHED VERSION; this is the author's final, peer-reviewed manuscript. The published version may be accessed by following the link in the citation at the bottom of the page.

Table 3: H2-Higher Empathy Associated with Higher Willingness to

\section{Relinquish Control}

\begin{tabular}{|c|c|c|}
\hline & $\begin{array}{l}\text { I would want a } \\
\text { patient to interrupt } \\
\text { if I suggested a } \\
\text { treatment contrary } \\
\text { to his or her } \\
\text { religious beliefs }\end{array}$ & $\begin{array}{l}\text { I would not } \\
\text { feel comfortable } \\
\text { discussing } \\
\text { religious topics } \\
\text { unless the } \\
\text { patient brought } \\
\text { it up first }\end{array}$ \\
\hline \multicolumn{3}{|l|}{ Control variables } \\
\hline Age & -.086 & -.012 \\
\hline Gender & -.055 & -.105 \\
\hline $\mathrm{RN}$ experience & -.209 & .069 \\
\hline$R^{2}$ change & .033 & .012 \\
\hline \multicolumn{3}{|l|}{ Empathy } \\
\hline $\begin{array}{l}\text { View of world from patient } \\
\text { perspective }\end{array}$ & -.221 & .135 \\
\hline $\begin{array}{l}\text { Understanding patient } \\
\text { experience }\end{array}$ & .430 & .038 \\
\hline Ignoring emotions & .082 & $-.585^{b}$ \\
\hline Thinking like the patient & -.089 & -.038 \\
\hline$R^{2}$ change & $.103^{a}$ & $.194^{c}$ \\
\hline Multiple $R$ & .368 & .453 \\
\hline Adjusted $R^{2}$ & .075 & .150 \\
\hline Overall ANOVA & $F_{7.101}=2.257, p<.05$ & $F_{7.101}=3.733, p<.001$ \\
\hline$N$ & 109 & 109 \\
\hline
\end{tabular}

$$
\begin{aligned}
& { }^{\circ} p<05.05 \\
& { }^{b} p<01.0 \\
& { }^{c} p<.001
\end{aligned}
$$


NOT THE PUBLISHED VERSION; this is the author's final, peer-reviewed manuscript. The published version may be accessed by following the link in the citation at the bottom of the page.

Table 4: H3-Higher Intrinsic Religiosity Associated with Willingness to

\section{Relinquish Control}

\begin{tabular}{lll}
\hline & $\begin{array}{l}\text { I would want a patient } \\
\text { to interrupt if I } \\
\text { suggested a treatment } \\
\text { contrary to his or her } \\
\text { religious beliefs }\end{array}$ & $\begin{array}{l}\text { I would not feel } \\
\text { comfortable } \\
\text { discussing religious } \\
\text { topics unless the } \\
\text { patient brought } \\
\text { it up first }\end{array}$ \\
\hline Control variables & & \\
Age & -.161 & .011 \\
Gender & -.062 & -.097 \\
RN experience & $-.232^{\mathrm{d}}$ & .040 \\
$R^{2}$ change & .033 & .012 \\
Religiosity & & \\
Intrinsic & $.295^{\mathrm{b}}$ & -.136 \\
Extrinsic & .032 & .132 \\
$R^{2}$ change & $.081^{\mathrm{a}}$ & .045 \\
Multiple $R$ & .337 & .239 \\
Adjusted $R^{2}$ & .070 & .011 \\
Overall ANOVA & $F_{5,103}=2.630, p<.05$ & $F_{5,103}=1.244, p=.294$ \\
$N$ & 109 & 109 \\
\hline
\end{tabular}

${ }^{a} \mathrm{p}<, 05$

${ }^{\mathrm{b}} \mathrm{p}<\mathrm{01}$.

${ }^{c} p<.001$

${ }^{a} p<05$, one-way. 
NOT THE PUBLISHED VERSION; this is the author's final, peer-reviewed manuscript. The published version may be accessed by following the link in the citation at the bottom of the page.

Table 6: H4-Empathy Will Act as an Intervening Variable, Diminishing Impact of Religiosity on Willingness to Relinquish Control

\begin{tabular}{|c|c|c|}
\hline & $\begin{array}{l}\text { I would want a } \\
\text { patient to interrupt } \\
\text { if } 1 \text { suggested a } \\
\text { treatment contrary } \\
\text { to his or her religious } \\
\text { beliefs }\end{array}$ & $\begin{array}{l}\text { I would not feel } \\
\text { comfortable } \\
\text { discussing religious } \\
\text { topics unless the } \\
\text { patient brought } \\
\text { it up first }\end{array}$ \\
\hline \multicolumn{3}{|l|}{ Control variables } \\
\hline Age & -.067 & -.068 \\
\hline Gender & -.067 & -.099 \\
\hline RN experience & $-.233^{\mathrm{d}}$ & .064 \\
\hline$R^{2}$ change & .003 & .012 \\
\hline \multicolumn{3}{|l|}{ Empathy } \\
\hline $\begin{array}{l}\text { View of world from patient } \\
\text { perspective }\end{array}$ & -.046 & .047 \\
\hline $\begin{array}{l}\text { Understanding patient } \\
\text { experience }\end{array}$ & .333 & .061 \\
\hline Ignoring emotions & .022 & $-.532^{b}$ \\
\hline Thinking like the patient & -.105 & .042 \\
\hline$R^{2}$ change & $.103^{a}$ & $.194^{\mathrm{c}}$ \\
\hline \multicolumn{3}{|l|}{ Religiosity } \\
\hline Intrinsic & $326^{c}$ & $-.163^{d}$ \\
\hline Extrinsic & .035 & .110 \\
\hline$R^{2}$ change & $.095^{\mathrm{b}}$ & $.047^{a}$ \\
\hline Multiple $R$ & .480 & .503 \\
\hline Adjusted $R^{2}$ & .160 & .185 \\
\hline Overall ANOVA & $F_{9.99}=3.292, p=.002$ & $F_{9,99}=3.716, p<.001$ \\
\hline$N$ & 109 & 109 \\
\hline
\end{tabular}

\footnotetext{
${ }^{a} \mathrm{p}<.05$

${ }^{\mathrm{b}} \mathrm{p}<0.01$

${ }^{c} p<.001$

${ }^{\circ} \mathrm{p}<05$, one-tailed
} 